\title{
THE HYPO BANK CASE: HOW THE CROATIAN CONSTITUTIONAL COURT (MIS)INTERPRETED THE HISTORICAL MEANING OF THE PRINCIPLE OF LEGALITY
}

\author{
Igor VULETIĆ \\ Associate Professor, Department of Criminal Law, \\ Faculty of Law, Josip Juraj Strossmayer University of Osijek; \\ E-Mail: ivuletic@pravos.hr

\section{Mato PALIĆ} \\ Assistant Professor, Department of Constitutional Law, \\ Faculty of Law, Josip Juraj Strossmayer University of Osijek; \\ E-Mail:mpalic@pravos.hr
}

\begin{abstract}
Croatia has undergone significant infrastructural changes since the 1990s. The difficult process of transition to statehood caused far-reaching consequences of unemployment, increase of domestic and foreign debt, and growth of systemic corruption. In 2010 the Croatian Parliament amended the Constitution and abolished the statute of limitations for privatization and ownership transformation crimes committed during the Homeland War and peaceful reintegration. The abolition of the statute of limitations enabled Croatian justice to prosecute former Prime Minister Ivo Sanader for his part in war profiteering during the early 1990s, with the result that he was sentenced to long-term imprisonment in the Hypo bank case. However, in 2015 the Constitutional Court overruled this ruling, arguing that the abolition of retroactivity cannot be applied to those criminal offences for which the statute of limitations has expired before the Constitutional amendment entered into force. This decision made all criminal proceedings against war profiteers legally impossible, since in almost every case the statute of limitations had already expired in 2010. In this text, authors will analyze the decision of the Constitutional Court
\end{abstract}


in the Hypo bank case, critically examining the reasoning of the Constitutional Court in the context of historical interpretation of the nullum crimen sine lege, nulla poena sine lege principle - as one of the most esteemed values of enlightenment philosophy concluding with an explanation of their own standpoint on the topic.

Key words: statute of limitations - abolition - principle legality - Hypo bank case - Croatian constitution

\section{INTRODUCTION: POLITICAL AND LEGAL BACKGROUND OF THE CASE}

The dissolution of the former Socialist Federative Republic of Yugoslavia (SFRY), a state union which stretched across the Western part of the Balkan peninsula with a population of over twenty million, started during the eighth decade of the twentieth century. The death of the unparalleled political leader, Marshall Josip Broz Tito (1980), and the ensuing high inflation rate with the devaluation of the currency, as well as a general economic crisis, gradually led to social and political unrest, which eventually caused the dissolution of this large and once very influential country. This process resulted in bloody wars, first in Croatia and then in Bosnia and Herzegovina.

The unsustainability of the then existing economic system was visible even during the eighth decade of the twentieth century. At the time, there was a growing awareness in Croatia and Slovenia of the market economy system. This marked the introduction into the processes of economic transformation and privatization. The economic transformation represented legal transformation of previous community property into property with clearly determined owners (private or state). The privatization process represented selling state property to private entities (Josipović, 2018, pp. 197 - 199). Croatia has opted for a market economy in its Constitution from 1990, which enacted a package of laws accommodating the implementation of the process of economic transformation and privatization. Although this process was well designed in essence, it failed miserably in practice. Instead of serving as a transition instrument from a socialist to a capitalist society, the privatization process was used as a tool for the unjustified enrichment of a small group of people who had close connections to the top ranks of the Croatian Democratic Community party (CDC). Marked by the absence of transparency and a strong political influence, the privatization process hindered the economic growth of the country and had a dissuasive effect on potential foreign investors, which directly caused the deterioration of the country's economic structure (Gregurek, 2001, pp. 155). Croatian literature does not contain systematic criminological studies which would contribute to the determination of the exact number of criminal offences 
The Hypo bank case: How the Croatian Constitutional Court...

related to the economic transformation and privatization, as well as wartime profiteering, which is usually reviewed in this context. It can only be assumed that the number of crimes in this area is considerable. A series of judicial factors also contributed to the situation, including long and inefficient criminal proceedings, as well as a small number of verdicts for such cases. Drawing a parallel with Durkheim's anomie theory, Novoselec, Roksandić Vidlička and Maršavelski rightfully note that Croatia was in a state of anomie at the time, which led to the creation of innovative forms of unjust enrichment through the privatization process (Novoselec, Roksandić Vidlička and Maršavelski, 2015, p. 201).

Considering the described situation and its long-term negative consequences for the economic stability of the Croatian society, and acknowledging the justified interest for sanctioning those responsible for such a situation, the founders of the Croatian constitution undertook a daring constitutional reform in 2010. Propelled by the array of legal reforms, with the common goal of a final reckoning of systematic corruption, the Parliament adopted a constitutional amendment according to which criminal offences related to economic transformation, privatization and wartime profiteering were elevated to the level of the most severe crimes (such as genocide and war crimes) by eliminating their statute of limitations (Article 31 Paragraph 4 of the Constitution).

A contentious question was whether this amendment could be applied to the criminal offenses whose statute of limitation had already elapsed at the time of the adoption of the Constitutional amendment or whether the statute of limitations could no longer be derogated in such cases. To clarify this issue, a special Law on the Elimination of the Statute of Limitations for Criminal Offenses of Wartime Profiteering and the Criminal Offenses and Process of Economic Transformation and Privatization was enacted in 2011. This Law clearly opted for the possibility that the elimination of the statute of limitations would apply equally to the specified criminal offences, regardless of whether their statute of limitation had already elapsed. The legislator allowed expressis verbis the application of the elimination of the statute of limitations to all such criminal offences, even in cases where the lapse of the statute of limitations was previously determined by a binding court decision (Novoselec and Novosel, 2011 , pp. 603 - 620). This would have been the final resolution on this matter, if not for the decision cited in title of this paper: the decision of the Constitutional Court of the Republic of Croatia in the "Hypo Bank" case. In this decision, the Constitutional Court took a position which was contrary to the expressed will of the writers of the constitution and the legislature. Considering the role of the Constitutional Court, which was defined in the structure of the Croatian judicial system, this decision imposed significant legal consequences for all future trials. This is even more evident considering the political implications of the "Hypo Bank" case, as the case was against the formerly powerful Prime Minister of Croatia, Ivo Sanader. The following sections 
contain the chronology of the "Hypo Bank" case, the analysis of the decision of the Constitutional Court regarding the issue of limits to the elimination of the statute of limitations and our critical reflections on this significant issue.

\section{THE HYPO BANK CASE - FACTS AND CHRONOLOGY}

In the following section we will explain the circumstances and the chronology of the entire Hypo Bank case, starting with the indictment, through the first instance and appellate decision, to the decision of the Constitutional Court and the ensuing repeated trial. We will also provide a closer insight into the reasoning of the decision of the Constitutional Court regarding the scope of the retroactive application of the elimination of the statute of limitations for wartime profiteering and criminal offences related to economic transformation and privatization.

\subsection{Overview of the facts and chronology of the "Hypo Bank" case}

Ivo Sanader was the Prime Minister of Croatia for two terms, from 2003 to 2007 and from 2007 to his abrupt and never fully explained resignation in 2009, after his second mid-term. In the Hypo Bank case, he was accused of wartime profiteering which he allegedly committed during his time as the Deputy Minister of Foreign Affairs, during the years that Croatia was seeking a bank which would be willing to provide an affordable loan for the purchase of the buildings of Croatian embassies abroad. Sanader was chosen to conduct the negotiations for Croatia as Deputy Minister and a person who enjoyed the Prime Minister's trust. This was also due to the fact that he was a fluent German speaker, having lived in Austria for years where he obtained his Ph.D. in literature in 1982. Thus, the Minister of Foreign Affairs entrusted him to conduct these negotiations in their entirety.

According to the indictment of the Office for Combating Corruption and Organized Crime (OCCOC) on August 31, 2011, Sanader was charged for arranging an illicit cash provision for himself in the amount of 7 million Austrian Schillings (around \$580,000) which was ultimately paid by the Austrian Hypo Bank, Die Kärntner Landesbank Klagenfurt, with whom Sanader was acting as an authorized negotiator for the Croatian government. This was done in 1994 and 1995, during the Homeland War, when the Republic of Croatia was facing difficulties finding banks which would provide affordable loans due to its difficult economic situation. This provision was paid to Sanader as a "reward" for allowing the bank's entry into the Croatian economy. After the trial before the County Court in Zagreb, on November19, 2012, Sanader was found guilty as charged and convicted to three years and six months in prison, with a mandatory confiscation of financial gains in the abovementioned amount. Upon appeal, the Supreme Court of the Republic of Croatia reduced 
Sanader's prison sentence to three years in 2014, but it confirmed the conviction.

Thereupon, Sanader's legal team filed a constitutional claim to the Constitutional Court. In their view, such conduct was a violation of the legality principle and the rule of prohibiting the retroactive application of a less favorable law (nullum crimen sine lege, nulla poena sine lege praevia). Therefore, the issue that the Constitutional Court was presented with regarding Sanader's claim was: Can the Constitutional amendment of the elimination of the statute of limitations for the criminal offences of wartime profiteering be applied to the criminal offences whose statute of limitations had already lapsed at the time of the adoption of this Constitutional amendment? If the answer to this question is affirmative, it would mean that the statute of limitations for such criminal offences would be eliminated, and they could once again be prosecuted. The practical aspect of this issue is reflected in the fact that, at the time of the enactment of the Constitutional amendment, the statute of limitations had lapsed for the majority of the relevant criminal offences. Therefore, a positive determination of this issue would effectively enable the processing of transformative crimes in the judicial practice. On the other hand, a negative response would practically preclude the initiation of the majority of criminal proceedings and render this constitutional provision into law in the books.

The Constitutional Court reached a decision in this case on July 24, 2015, in which it basically accepted Sanader's arguments. Regarding the issue at hand, the Constitutional Court concluded that the constitutional provision on the elimination of the statute of limitations cannot be applied to cases for which the statute of limitations had already lapsed at the time of the adoption of the Constitutional Amendment. In other words, the Constitutional Court determined that in such cases the statute of limitations cannot be re-opened. In its reasoning, the Court started with the understanding that the legality principle represents a minimal guarantee of the defendant's legal security, which can never be derogated, even at the will of the constitutional authority. Here the Court relied on a confusing method of combined enumeration of legal provisions which should be applied in the given case and the citation of sections of various decisions of the Supreme Court and the European Court for Human Rights (ECHR). As Josipović rightfully notes, the course of the elaboration is not consistent, which makes this decision (immense in volume as it runs to 187 pages) difficult to follow at times, or to discern what exactly the Constitutional Justices had in mind. In addition, certain enumerations are superfluous, and it is thus unclear why, for example, the Constitutional Court speaks about the mandatory application of the law with the more favorable sentencing framework, when the applicant was not objecting to this matter, and this issue was not contested at all in this case.

Furthermore, another confusing factor is the citing of sections of certain decisions of the ECHR, which clearly refer to the legality principle, but which 
the Court failed to place into the context of the specific claim, as it is not completely clear what these decisions should refer to. All of this, with the abovementioned volume of the decision and the fact that the decision was being made on two consolidated cases, contributed to the confusion.

Considering the central position undoubtedly given to the legality principle in the Croatian legal tradition, the Court found that Article 31 Paragraph 4 of the Constitution should be interpreted restrictively, which would lead to the conclusion that this provision can, under no circumstances, "derogate the statutory provisions on statutes of limitations", because the latter are a "general principle of law", which is accepted by all civilized nations in the world (Josipović, 2018, p. 154). In this context, the Court strongly emphasizes the practice of the ECHR, which affirms the legality principle as the fundamental principle which ensures the principle of the tripartite division of government, guarantees the functionality of the criminal legislation and protects from arbitrary conduct. Sections of numerous decisions of the ECHR are cited, which confirm this thesis, in the view of the Court. It is particularly interesting that the Constitutional Court relies on one decision from the American judicial practice (which is not typical for courts from the Continental European legal tradition), the Stogner vs California case, which is erroneously presented as a decision of the US Supreme Court.

Accordingly, this principle must be continuously "built and implemented" in national practice (Josipović, 2018, p. 154). In the view of the Court, in cases related to the issue of the elimination of the statute of limitations for wartime profiteering, this should be pursued through three steps: the competent court first must establish the existence of sufficient evidence that a specific economic crime was committed; thereafter, it should be determined that the statute of limitations for this (plain) economic crime itself had not lapsed; only after this was established by the competent court, it can proceed to the determination of the fulfillment of the requirements from Article 7 Paragraph 1 of the Law on the Elimination of the Statute of Limitations, based on which a plain economic crime is qualified as wartime profiteering, if the requirements are met (Josipović, 2018, pp. 154 - 160). Thus, the Court here suggests that the first determination should be whether or not the crime was committed, and only then whether or not the statute of limitations had lapsed, which is the reverse logic to the one normally applied by courts in the Republic of Croatia. The courts usually (and in accordance with the rules) first establish the existence of socalled procedural impediments to the trial, including the statute of limitations, and only then do they proceed to the hearings and decisions on the merits of the case (Josipović, 2018, p. 232).

Considering all the presented arguments, the Constitutional Court accepted the objections of the applicant, annulled the decisions of the Supreme Court and the County Court, and it remanded the case back to the first instance court (which was the County Court in Zagreb). Through this decision, the Court brought into question the viability of all current and future proceedings for 
The Hypo bank case: How the Croatian Constitutional Court...

wartime profiteering and crimes related to economic transformation and privatization.

\section{CRITICAL COMMENTARY}

The following is a closer reflection on the decision of the Constitutional Court, as well as a critical commentary in the following section. In our view, the Hypo Bank case creates dilemmas of criminal and constitutional law. The commentary of the decision will first analyze it from the perspective of criminal law, and then from the perspective of constitutional law. We emphasize that both perspectives are equally important.

\subsection{Criminal law perspective}

There is no doubt that the legality principle is one of the fundamental principles, if not the most significant principle, of Croatian substantive criminal law. However, one could rightfully ask whether the interpretation of this fundamental principle by the Constitutional Court is accurate, or could the Court have chosen a "better route" (Ivičević Karas and Roksandić Vidlička, 2017, p. 241)?

In our view, the interpretation of this principle, from the perspective of criminal law, is in essence based on the wrong premise. The legality principle only refers to two components: the criminal offence and the prescribed sentence. This undoubtedly arises out of applicable Croatian law. The Constitution itself mentions, in Article 31 Paragraph 1, the "criminal offence" and "punishment", while the Criminal Code extends this term to "criminal sanctions". This is logical, taking into consideration that this principle was historically formulated as a reaction to the self-will and arbitrariness of the medieval courts, especially in determining punishable conduct and the appropriate punishments.

Croatian criminal law theory clearly defines the scope of the legality principle based on the two aforementioned segments. A contrario, which means that this principle does not refer to the issue of statute of limitations and that the issue of retroactive application of the extended (unfavorable) statute of limitations term should not even be considered in relation to the principle of nullum crime sine lege praevia, as the Constitutional Court had done. Such an approach is erroneous, not only for the previously stated reason, but also because the prohibition of the retroactive application can only refer to institutes of a purely substantive nature. On the contrary, procedural institutes can be applied retroactively. This position was explicitly confirmed by the Croatian Supreme Court. The statute of limitations does not have a purely substantive nature in Croatian criminal law. As a matter of fact, Krapac invokes the fact that the lapse of the statute of limitations leads to a decision of rejecting the claim, which is not a decision resolving the merits (substantive issues) of the case. Thus, he defines it as a purely procedural institute (Krapac, 2015, p. 48). Other scholars 
claim that the statute of limitations is an institute of a mixed nature, substantive and procedural (Novoselec, 2016, p. 264). We are in favor of this position. The argument presented by Krapac is accurate, but it is also true that the statute of limitations is provided in the Criminal Code and that it is connected to the prescribed sanction, which are both substantive categories. Therefore, if one starts with the presumption that the statute of limitations is not an institute of a purely substantive nature, then the principle of the prohibition of retroactive effects does not apply to it at all.

Furthermore, as previously mentioned, the Constitutional Court cites, in several instances, sections of various decisions of the ECHR. Josipović warns that the interpretation of these decisions by the Constitutional Court is one-sided and that the Court only cites the sections of the decisions which support its position, and that it interprets them out of context. To the contrary, as noted by Josipović, there is no ECHR case law which ties the prohibition of retroactive application of the criminal code to the statute of limitations and its term (Josipović, 2018, p. 239).

It can generally be stated that the ECHR has not developed a sufficiently clear and consistent jurisprudence on the issue of the prohibition of retroactive application of criminal codes (Valentini, 2011, p. 194). It is even notable that the ECHR case law related to the legality principle and the limits to the interpretation of Article 7 of the EHRC set the opposite trend to the one pursued by the Croatian Constitutional Court. The ECHR took the more extensive and flexible approach of the Anglo-American concept of the principle of legality. A good example of this is one of the landmark cases of the ECHR in this area, the S.W. vs. UK case. The applicant in this case was "S", who was convicted for raping his wife in Great Britain, although marital rape was not a crime at the time it was committed,due to the existence of the so-called marital immunity. The ECHR rejected his argument on the prohibition of retroactivity, stating that the conviction of the British courts was "reasonably predictable" because it was in accordance with the contemporary public discourse in Great Britain, and gender equality in general.

Novoselec is right to conclude that the Constitutional Court, through the Hypo Bank decision, actually modified the will of the writers of the constitution and indirectly abolished the previously cited provision of Article 31 Paragraph 4 of the Croatian Constitution (Novoselec, 2016, p. 273). The question of whether or not the Constitutional Court was authorized to take such a step will be addressed it the following section. 


\subsection{Constitutional law perspective}

It is important to note that the first President of the Republic of Croatia did not declare war based on the previous decision of the Croatian Parliament. For this reason, the constitutional provision eliminating the statute of limitations also extends to the term "immediate endangerment of the independence and territorial of the country". Considering the fact that constitutional norms are characteristically broad and vague, their further interpretation is realized, as a rule, through laws and bylaws (Smerdel, 2013, p. 125). For this reason, the concretization of these provisions was done through the enactment of the Law on the Elimination of the Statute of Limitations for Criminal Offences of Wartime Profiteering and Criminal Offences Related to Economic Transformation and Privatization.

The significance of the decision of the Constitutional Court of the Republic of Croatia in the Hypo Bank case arises out of several facts. First this decision was the first instance in which the Constitutional Court interpreted the constitutional norm on the elimination of the statute of limitations for certain criminal offences, whereby it took the position which will be followed in future similar cases, in accordance with the stare decisis principle (Potočnjak and Stresec, 2009 , p. 209). Another fact is its binding nature for the courts whose decisions were overturned in the parts relevant to the legal position taken by the Constitutional Court. Therefore, although they are not formally obliged to do so, other courts in similar cases will adopt the legal interpretation of the Constitutional Court, because they would otherwise risk their decisions being set aside.

The third significant matter is the fact that the Constitutional Court in this case, de facto conducted a review of the substantive constitutionality of a constitutional norm. Constitutional review of laws in countries of the continental European legal tradition, including the Republic of Croatia, is in the jurisdiction of constitutional courts and it entails the abstract and direct review of the constitutionality of laws. A different approach is taken in the USA, for example, where all courts conduct constitutional reviews, but these reviews are indirect and case-specific. These differences have significant legal consequences (Smerdel, 2013, pp. 136 - 142). According to the existing constitutional order, the constitutional review of the provisions of legal norms is conducted upon a proposal or request, and not in decisions based on constitutional claims. The purpose of filing a constitutional claim is the protection of constitutional and convention rights. Furthermore, the Constitutional Court concluded in a number of previous decisions that it does not have the jurisdiction to evaluate the substantive constitutionality of a constitutional provision.

The accurate position on the constitutional grounds for the decision of the Constitutional Court in the Hypo Bank case entails finding the answers to several principal self-imposing questions and sub-questions. The first one refers 
to the possibility of a retroactive effect of a constitutional norm, the second to the possibility of interfering with the legality principle with the application of the proportionality principle, and the third to the interaction of the highest values of the constitutional order, i.e. finding an appropriate balance between their inherent demands. Considering the exceptional constitutional significance of the highest values of the constitutional order which arises out of their function, it should be noted that they could collide in practice. The text of the constitution does not explicitly distinguish between them, so the Constitutional Court of the Republic of Croatia has the duty to create certain standards through its practice, in accordance with the spirit of the Constitution as a whole and in line with the contemporary methods for the interpretation of legal norms.

The possibility of the retroactive application of a constitutional norm stems from the fact that the retroactive application of certain provisions of law is allowed in exceptional cases, when there are justifiable circumstances. Considering the fact that the constitution sets forth the legal and political order and that the constitutional norms are the cornerstone for the enactment of laws and all other regulations, it would be logically and constitutionally unacceptable to allow the retroactive application of a legal norm of a weaker legal force, but to prohibit at least an equal possibility for constitutional norms. Such a position would represent a complete inversion of the fundamental principles underlying the objective constitutional order in the Republic of Croatia. Furthermore, it should be explained whether retroactive application is constitutionally allowed, regardless of the specific right and liberty it refers to. The answer to this question is negative. The Constitution itself excludes the possibility of limiting certain rights and liberties, even during wartime. This includes the right to life, the prohibition of torture, cruel or demeaning conduct, the legal determination of criminal offences and sanctions, as well as the freedom of thought, conscience and religion.

These rights and liberties are of absolute character and they cannot be derogated. Croatian Constitution stipulates that, even in cases of clear and present danger to the existence of the state, no restrictions may be imposed upon the provisions of this Constitution stipulating the right to life, prohibition of torture, cruel or degrading treatment or punishment, and concerning the legal definitions of criminal offences and punishment, and the freedom of thought, conscience and religion (art. 17. par. 3). Therefore, all other rights and liberties can be subject to limitations, but only in accordance with the prescribed preconditions. The Constitution sets forth three fundamental preconditions. The first is the form of the act prescribing the limitation, the second is the existence of legitimate goals, and the third is adherence to the proportionality principle. Rights and liberties can only be limited through a legal or constitutional norm. Although the constitutional norms were not explicitly mentioned as a means for limiting rights and liberties. This possibility implicitly arises out of the concept of the Croatian constitutional order. The Constitution lays out four fundamental legitimate goals - the rights and liberties of others, the legal order, public 
morals and health. Finally, the proportionality principle demands a proportional relationship between the desired legitimate goal and the severity of the intrusion into the constitutionally guaranteed rights and liberties (Palić and Vencel, 2017, pp. $490-492$ ).

In addition to the Constitution of the Republic of Croatia, for an accurate assessment of the possibility of encroaching into the proportionality principle in criminal law, which is also recognized as an international normative standard, the international legal norms which are applicable in the legal system of the Republic of Croatia must be taken into account. These are the Convention on the Protection of Human Rights and Fundamental Liberties which was ratified by the Croatian Parliament in 1997 and the Charter of Fundamental Rights of the European Union which is an integral part of the Constitutional Agreement from Lisbon and which entered into force with the accession of the Republic of Croatia into the European Union. The Croatian Constitution distinguishes between two types of international agreements. The first category is subject to mandatory ratification by the Croatian Parliament, while the other is signed and enforced by the executive branch, i.e. the Government of the Republic of Croatia and the President of the Republic of Croatia. The mandatory ratification process is reserved for the international agreements which aim to amend legislation, create financial obligations for the Republic of Croatia, or those of a military and political nature. Both of the aforementioned international agreements were ratified by the Croatian Parliament and have a higher legal force than national laws ex constitutione. However, ratified international agreements cannot match the legal force of the Constitution because, on the one hand, they were not enacted following the procedure for the enactment of the Constitution of the Republic of Croatia, and on the other, they enter the Croatian legal system on the basis of a constitutional norm. All these legal acts contain the legality principle in the realm of criminal law.

When reaching this decision on the constitutional claim, the Constitutional Court of the Republic of Croatia made a leap in the interpretation of its constitutional authority, by assessing the constitutionality of a provision of the Constitution itself, which provided for the elimination of the statute of limitations for wartime profiteering and crimes related to economic transformation and privatization which were committed during the Homeland War and peaceful reintegration, wartime and the imminent danger to the independence and territorial integrity of the country. The constitutionality principle, as one of the fundamental principles set forth by the Constitution of the Republic of Croatia and entails the review of the constitutionality of norms of a lower legal force. The jurisdiction of the Constitutional Court in this regard is expressly set forth in the Constitution and this normative framework does not explicitly allow for the possibility of abstract constitutional review of any constitutional norm. Each amendment to the Constitution, regardless if it was introduced in the Croatian Parliament or by means of a constitutional referendum, has the identical legal effect on the legal force of the new norms 
which are incorporated into the text of the Constitution. Considering these facts, it is unclear why the Constitutional Court of the Republic of Croatia potentially stepped outside of the scope of its constitutional authority. In part, the Constitutional Court draws the justification for such a position from the significance of the highest values of the constitutional order of the Republic of Croatia which play a key role in the interpretation of all other constitutional norms, including the one eliminating the statute of limitations for certain criminal offences. The concept which supports the arguments of the Constitutional Court has two main viewpoints.

According to the first one, the lapse of the statute of limitations has an absolute and irreversible effect, which cannot be interfered with subsequently, because this would violate the legality principle which is an integral part of the rule of law, as one of the highest values of the constitutional order.

The second viewpoint is purely interpretational, according to which the Constitutional Court interprets the will of the constitutional authority. It states that only a limited scope of application of the constitutional provision on the elimination of the statute of limitations is possible, only for criminal offences whose statute of limitations had not lapsed at the time of the enactment of the Constitutional Amendment.

With regard to the first position, the legality principle in criminal law does not consist only of the prohibition of retroactive application. The prohibition of retroactive application arises out of the necessary protection of the principle of legal security, which is an integral part of the rule of law. There are several segments of the absolute prohibition of retroactive application, which are constitutionalized. The violation of the legal determination of criminal offences and sanctions is absolutely prohibited. Otherwise, it would be possible to retroactively incriminate and sanction conduct and to pronounce sentences which did not even exist at the time the conduct was committed. This would allow absolute arbitrariness in the conduct of the government, as the constitution exists precisely to prevent such behavior. The significance of this prohibition also arises out of the simple fact that it cannot be encroached in any way through the application of the proportionality principle, even during wartime or a state of emergency. Furthermore, the Constitution of the Republic of Croatia also prohibits the retroactive application of sanctions by prescribing the obligation of choosing the more favorable sanction, if it was changed for a certain criminal offence during the course of the criminal proceedings. The sanction is, without a doubt, a substantive part of the body of a criminal offence. The statute of limitations for the initiation of criminal proceedings is not of a purely substantive nature. The prohibition of retroactive interference with the statute of limitations could only be accepted if the exclusively substantive component of the statute of limitations could be consistently defended. However, there is no unified or prevailing position in the criminal legal theory, which was acknowledged by the Constitutional Court in its reasoning for the decision in the Hypo Bank case. If the Constitutional Court held the position 
that a retroactive intervention into the statute of limitations was not possible, then it should have provided additional arguments in support of the purely substantive component of the statute of limitations for the initiation of proceedings. However, the reasoning for such a decision does not contain any such arguments.

The second position through which the Constitutional Court limited the scope of a clearly formulated constitutional provision, from a purely linguistic perspective, is particularly debatable for several reasons. Firstly, none of the applicable methods of constitutional interpretation could lead to the conclusion that the intent of the writers of the constitution was to prevent the lapse of the statute of limitations only for the criminal offences which had not occurred at the time the revision of the Constitution of the Republic of Croatia, enacted in 2010. The linguistic and teleological interpretation can only lead to the conclusion that the writers of the Constitution intended to revive the lapsed statute of limitations. It is completely paradoxical for the Constitutional Court to conclude that this provision only extends to the criminal offences whose statute of limitations had not already lapsed. This raises the crucial question: why would the Constitution be amended in order to enable the prosecution of criminal offences whose statute of limitations had not lapsed? The lapse of the statute of limitations is a procedural impediment. If it had not lapsed, there are no procedural impediments whatsoever which would prevent the State Attorney from conducting legal actions aimed at sanctioning the perpetrators of certain criminal offences. It is precisely the conduct of the State Attorney that interrupts the course of the statute of limitations, so it is unclear why the Constitution of the Republic of Croatia would be amended to this effect. All of these considerations bring into question the logical viability and the legal grounds of the position taken by the Constitutional Court in its decision upon the constitutional claim in the Hypo Bank case. An additional argument which completely annuls the logic and reasoning of the Constitutional Court in relation to the second position is the fact that in the period from the beginning of the Homeland War until the enactment of the Constitutional Amendment in 2010 an interim Criminal Code was enacted, according to which the statute of limitation had lapsed for all the criminal offences covered by the Constitutional Amendment. Therefore, had the reasoning of the Constitutional Court been adopted, the Constitutional Amendment would not be applicable to them at all.

A special law had to be enacted in order to enable the application of the constitutional amendment eliminating the statute of limitations, which happened in 2011. This law precisely enumerated the criminal offences which were subject to this constitutional amendment.

Therein, three limitations were defined. The first one referred to the timeframe within which the criminal offence was committed, i.e. the Homeland War and the peaceful reintegration. The Croatian Constitution prescribes the declaration of war which is done by the President of the Republic as the commander in chief of the armed forces, based on the previous decision by the Croatian 
Parliament. This decision was formally never issued, but the practice of the Constitutional Court established that the Homeland War ended with the conclusion of the peaceful reintegration process under the auspices of the Organization of the United Nations on January 15, 1998. Criminal offences committed after this date could not be subject to the Constitutional Amendment on the elimination of the statute of limitations, unless there was another war declared or immediate endangerment of the independence and territorial integrity of the country. The second limitation, which is fully in line with the principle of proportionality in the limitation of rights, arises out of the constitutional provision which requires the legal prescription of such criminal offences, which precludes their prescription by legal norms of a lower legal force. The third limitation stems from the preceding two, because the law enumerates some, but not all of the criminal offenses which were prescribed by the Criminal Code, i.e. the laws which were applicable during the Homeland War.

In order to reach an appropriate conclusion related to the proportionality principle, we must answer the question of whether the legitimate goal, the sanctioning of those who obtained substantive benefits during the wartime, can be accomplished through the application of a measure more favorable than the interference with the statute of limitations. The answer to this question is negative. Considering the fact that the lapse of the statute of limitations precludes the initiation of proceedings, only the elimination of this fact can enable its initiation. There is no other measure or legal mechanism within the legal framework of the Republic of Croatia which would have the same effect. Thus, the crucial requirements of necessity and proportionality are met in this case. Considering the fact that the case at hand weighed the principle of legal security and social justice as significant constitutional values, it is our view that precedence should be given to social justice.

Due to the constitutional position of the Constitutional Court of the Republic of Croatia and the legal effect of its acts, the consequences of its decision on this constitutional claim and the sanctioning of wartime profiteers, which is the topic of this text, should be clarified. The general norm defining the binding nature of the decisions and orders of the Constitutional Court also applies to the decision in the Hypo Bank case. The special norm which applies to the proceedings on constitutional claims prescribes the mandatory adoption of the position of the Constitutional Court for the specific case. Thus, the legal interpretation provided by the Constitutional Court on the constitutional norm on the elimination of the statute of limitations for certain criminal offences is binding for the courts in the repeated trial, and basically all other courts deciding in similar cases.

Finally, the Constitutional Court, in the analyzed case, essentially modified the scope of a certain constitutional norm by limiting its legal effect. Such a move is an intrusion into the will of the constitutional authority. We find it indicative that the Constitutional Court did not react during the constitutional revision 
process in 2010, although it formally could have intervened and attempted to prevent the enactment of and unenforceable constitutional norm, nor did it annul the provisions of the law which restated the constitutional norm on the elimination of the statute of limitations in a manner inconsistent with the position of the Constitutional Court.

\section{CLOSING REMARKS}

The presented analysis indicates how robust the judicial practice in transitional countries can be, as well as describe its long-term effects on the affirmation of the idea of the rule of law. Placed in the appropriate historical and political context, the analysis of the decision of the Constitutional Court of the Republic of Croatia in the Hypo Bank case demonstrates that the Court both erroneously interpreted one of the central principles of criminal law, and exceeded its constitutional authority. Although the regular court in the remanded proceedings was able to take advantage of the newly created legal gap and to issue another guilty verdict, it is highly questionable whether this verdict will withstand the likely constitutional review by the Constitutional Court. This raises legitimate questions about the selection of Constitutional Court Justices and their accountability for the issued decisions, and questioning whether they are acting outside of their constitutional authority in reaching those decisions. It is our view that the Constitutional Court in Croatia needs to be "cleansed" from any type of political influence, which was done for the regular courts. Judges are selected by an independent body, the so-called State Judicial Council, whose absolute majority consists of professional judges, which minimizes any political influence. On the other hand, Justices of the Constitutional Court are selected by a two-third majority in Parliament, implying the need for consensus from both the ruling and opposition parties in order to be appointed. This means that only a person who is politically acceptable, as well as legally competent can qualify for such a position. It is worth noting in this context that five of the current thirteen Constitutional Court Justices were selected among individuals from previous political ranks, members of Parliament or ministers. Therefore, it would be useful to preclude the reappointment of justices in order to strengthen their independence from the political will of the members of the Croatian Parliament, similar to the German model. If a rule existed that the term of the justices is ten years, but without the possibility of reappointment, with retention of all the currently enjoyed privileges, this would certainly contribute to their independence. This would also improve the decisions quality of the Constitutional Court, as well as the legitimacy of these decisions in the professional and general public. 


\section{References}

\section{Books and articles}

Gregurek, M. (2001). The Scale and Effects of Privatization in Croatia. Ekonomski pregled, 1-2(52), 155 - 188.

Ivičević Karas, E., Roksandić Vidlička, S. (2017). The Relevance of Asset Recovery Policies in Transitional Societies: The Croatian Perspective. In Ligeti, K.,Simonato, M. (eds.), Chasing Criminal Money. Challenges and Perspectives On Asset Recovery in the EU (pp.229254). Oxford: Hart Publishing. http://doi:10.5040/9781509912087.ch010.

Josipović, I. (2018). The statute of limitations for cases of wartime profiteering and crimes related to economic transformation and privatization and the controversy following the decision of the Constitutional Court in the "Hypo Bank" case. Hrvatski ljetopis za kaznene znanosti i praksu, 2(25), $197-259$.

Krapac, D. (2015). Kazneno procesno pravo. Knjiga prva: Institucije [Criminal Procedure Law, Institutions]. Zagreb: Narodne novine.

Novoselec, P. (2009). Uvod u gospodarsko kazneno pravo [Introduction to Economic Criminal Law]. Zagreb: Pravni fakultet, Poslijediplomski studij kaznenopravnih znanosti.

Novoselec, P., Novosel, D. (2011). The elimination of the statute of limitations for the criminal offences of wartime profiteering and criminal offences related to economic transformation and privatization, Hrvatski ljetopis za kaznene znanosti i praksu, 2(18), 603 - 620.

Novoselec, P., Roksandić Vidlička, S., Maršavelski, A. (2015). Retroactive prosecution of transitional economic crimes in Croatia. Testing the legal principles and human rights in v. Erp, J., Huisman, W., Vande Walle, G. (eds.). The Routledge Handbook of White-Collar and Corporate Crime in Europe. New York, Routledge, Taylor \& Francis Group.

Novoselec. P. (2016). Opći dio kaznenog prava. Peto, izmijenjeno izdanje [Criminal Law general part]. Osijek: Pravni fakultet.

Palić, M., Vencel, C. (2017). The Problems with the Interpretation of Constitutional Norms in the Decision of the Constitutional Court of the Republic of Croatia in the "Hypo", Zbornik radova Pravnog fakulteta u Splitu, 2(17), 485 - 502.

Potočnjak, Ž., Stresec, M. (2009). The European Court for Human Rights and the Constitutional Court of the Republic of Croatia in the Protection of 
Human Rights, the Croatian Constitutional Jurisprudence - de lege lata and de lege ferenda. Zagreb: The Croatian Academy of Sciences and Arts.

Smerdel, B. (2013). Ustavnopravno određenje europske Hrvatske [Constitutional determination of European Croatia]. Zagreb: Narodne novine.

Valentini, V. (2011). "European Criminal Justice and Continental Criminal Law - A Critical Overview”, European Criminal Law Review, 1(2), $188-202$.

\section{Court decisions}

Constitutional Court of Croatia, No. U-III-4149/2014; available at: https://narodnenovine.nn.hr/clanci/sluzbeni/full/2015_08_89_1753.htl ; accessed on 6 December 2020.

County Court in Zagreb, No. 7 K-US-26/11; available at https://sudovi.hr/hr/zszg/sudska-praksa/sudska-praksa; accessed on 6 December 2020.

Supreme Court of Croatia, No. I Kž-Us 94/2013; available at https://sudskapraksa.csp.vsrh.hr/search; accessed on 6 December 2020.

Supreme Court of Croatia, No I Kž-235/93; available at https://sudskapraksa.csp.vsrh.hr/search; accessed on 6 December 2020.

S.W. vs UK, App no 20166/92 (EctHR, 22 November 1995); available at file://C:/Users/Igor\%20Vuleti\%C4\%87/Downloads/001-57965.pdf; accessed on 6 December 2020. 
